\title{
Using of Siwi Date in Production of Some New Juices
}

\author{
Fouad O. F. Abou-Zaid ${ }^{1}$
}

\begin{abstract}
Siwi cultivar is the most important simi-dry date cultivars in Egypt, its khalal stage has low price and marketing value as a result of its short shelf-life. So, this work aims to utilize Siwi fruits at khalal stage in production of new juices (pure or mixed with pomegranate or cinnamon), as well as evaluate these new juices chemically, sensory and microbiologically during three months of storage at room temperature. The obtained results showed that, date juice blends with pomegranate or cinnamon had higher content of polyphenols, flavonoids, anthocyanins in comparison with pure date juice, whereas pomegranate led to decrease TSS, reducing and total sugars in opposite situation with cinnamon. Also, adding pomegranate or cinnamon led to improve the microbial quality of the produced juices comparing to pure date juice. Results of sensory evaluation demonstrated that all studied date juices are accepted organoleptically. These mentioned results proposed that, Siwi date fruits at khalal stage (separately or combined with pomegranate or cinnamon) could be used in production of new, delicious and nutritional juices.
\end{abstract}

Key words: Siwi date fruits, khalal stage, pomegranate, cinnamon and juices.

\section{INTRODUCTION}

Date palm fruit (Phoenix dactylifera L.) could be considered as one of the most important fruits in dry and semidry areas (Chao and Krueger, 2007). Egypt is the first universal producer of date fruits, with 1590414 ton (FAO, 2019), this production represents about $18 \%$ of the universal date production. Date fruits could be categorized to three types, dry, semi-dry and soft. The most common soft types in Egypt are Samani, Zagloul, Hayani, Amhat, Bent- Aicha,...etc , whereas those of semi -dry dates are Siwi, Al-Amri, Al-Aglani, ...etc. and those of dry dates are Ebrimi, Barakawi, Sakouti,...etc (Youssef and Ramadan,1987). Tamr stage of Siwi date is the common processed stage either pitted or none pitted, while khalal stage has low price and marketing value as a result of its low shelf-life.

Developing new food products with high sensory acceptance as well as high nutritional value is stimulated by food market (Potter and Hotchkins, 1996). New juices development (using two or more kinds of fruits to obtain a juice that possessed both the used fruits nutritional values as well as a pleasant taste), has been encouraged by the food manufactures and consumers (Carvalho et al., 2007).

The important biological properties of pomegranate (Punica granatum L.) juice led to increase its popularity (Hyson, 2015). The health attributes of pomegranate fruits and by-products resulted in increasing their request recently (Schwartz. et al., 2009). Juice is one of pomegranate-derived products, which characterized by its high popularity between the super juice category, and is consumed all over the world as a result of its preferable flavor, aroma and color. Pomegranate healthy active nutrients with anticarcinogenic, antioxidants and antimicrobial activities could be utilized for human by consummation pomegranate juice (Al-Maiman and Ahmad, 2002; Waley et al., 2020).

Since ancient periods, the Egyptians and the Chinese have been used Cinnamon in foods and folk medicine (Elshafie, et al., 2012). Besides, its strong antibacterial, antioxidant, antipyretic (Lu et al.,2010) and antiinflammatory properties, which have a great role in repairing tissues (Molania, et al., 2012).

Cinnamon bark is used as one of the common spices and in tea making as well as an oriental herbal medicine for treating common colds, chronic gastrointestinal, cardiovascular and gynecological disorders (Hong, et al., 2012). In same trend, it is used also, as a remedy for cough, indigestion, sore throats, abdominal cramps, nausea, intestinal spasms, diarrhea and flatulence. Moreover, cinnamon has been showed an antifungal activity and retards food spoilage (Elahi, 2012 and Saber, 2019).

So, this work aims to maximize utilization of Siwi fruits at khalal stage in production of new juices with high nutritional values using either pomegranate or cinnamon, as well as evaluation of these new juices chemically, sensory and microbiologically.

\section{MATERIAL AND METHODS}

\section{Plant material and sampling:}

- Date palm fruits of Siwi cultivar at khalal stage were harvested from Siwa Research Station orchard in Matrouh, Egypt, during 2017 season. The obtained date fruits were selected for symmetry in size, color and free of both microbial damage and defects and as soon as fruits arrival to the laboratory (within $3 \mathrm{~h}$ maximum) they were used.

DOI: 10.21608/asejaiqjsae.2021.208390

${ }^{1}$ Agri- Industrialization Unit, Plant Production Department, Desert Research Center, Cairo, Egypt

Received October 25, 2021, Accepted, November 30, 2021. 
- Pomegranate fruits were purchased from local market in November 2017 in Cairo, Egypt.

- Cinnamon was purchased from local market in Cairo, Egypt.

- Chemicals and Solvents: were purchased from ElGomhoria Co. Cairo, Egypt.

\section{Juices preparation:}

\section{Date Juice:}

The selected date fruits were cleaned, washed carefully and deseeded manually, then divided into five groups each consisting of $3 \mathrm{~kg}$.

Date juice was produced throughout two major stages; extraction and filtration as follow:

- The extraction process: Washed and deseeded date fruits were cut into pieces and blended in electric blender with boiled water $(1: 1 \mathrm{w} / \mathrm{w})$ for $6 \mathrm{~min}(2 \mathrm{~min}$ intervals) then cold immediately.

- Filtration process: the cold extracted juice was filtered through muslin cloth and kept in polyethylene bags in deep freezer (-18C) till further use.

\section{Pomegranate juice preparation:}

Purchased Pomegranate fruits were washed and cut into pieces and arils were separated. These arils were blended in electric blender with tap water $(2: 1 \mathrm{w} / \mathrm{w})$ for $4 \mathrm{~min}$ (2min intervals) for extraction of juice, then filtered through muslin cloth and kept in polyethylene bags in deep freezer (-18C) till further use.

\section{Cinnamon preparation:}

The extract of cinnamon was made as described by Safithri and Fahma (2008). A total of $10 \mathrm{~g}$ of cinnamon powder was put into $100 \mathrm{~mL}$ of distilled water $(1: 10)$, then boiled in a closed-container for 15 minutes. The sample was filtered by using Muslin cloth, and the volume of resulted filtrate was measured. The distilled water was added to filtrate until the volume was $100 \mathrm{~mL}$ in total. The obtained solution was called the stock solution and then stored at $-18^{\circ} \mathrm{C}$ till further use.

\section{New juices formulations:}

Date juice was used for production of five new juices ( $2 \mathrm{~L}$ for each) as presented in table 1 .

All mentioned new date juices were pasteurized at $85^{\circ} \mathrm{C}$ for $10 \mathrm{~min}$, then the pasteurized date juices were hot filled in cleaned and sterilized glass bottles $(125 \mathrm{ml})$ and kept at room temperature for three months

\section{Assessment of quality parameters}

All previous new date juices were evaluated chemically and microbiologically at zero time, after one, two and three months, while sensory evaluation was achieved at zero time only.

\section{Total soluble solids (TSS):}

Brix values (TSS) of all studied juice blends were measured by digital refractometer (DR 6000, A. Kruss Optronic GmbH, Hamburg, Germany).

\section{Total and reducing sugars:}

Lane and Eynon method that described in AOAC, (2012), was used to determine total and reducing sugars.

\section{Acidity:}

Titratable acidity (as citric acid \%) was measured as follow: $10 \mathrm{ml}$ of juice sample was taken in a $250 \mathrm{ml}$ beaker and $50 \mathrm{ml}$ water were added into the beaker, then some drops of phenolphthalein indicator were added before titration using $0.1 \mathrm{~N}$ sodium hydroxide (AOAC, 2012).

pH value:

$\mathrm{pH}$ value was measured using a Systronic 324combination glass electrode $\mathrm{pH}$ meter at $25^{\circ} \mathrm{C}$.

Table 1. the formula of new Siwi date juice blends

\begin{tabular}{|c|c|c|c|c|c|}
\hline & $\begin{array}{l}\text { Date juice } \\
\quad(\%)\end{array}$ & $\begin{array}{l}\text { Pomegranate } \\
\text { juice }(\%)\end{array}$ & $\begin{array}{c}\text { Cinnamon } \\
\text { stock solution } \\
(\mathrm{ml}) \\
\end{array}$ & $\begin{array}{l}\text { Citric acid } \\
(\%) *\end{array}$ & $\begin{array}{c}\text { Guar gum } \\
(\%) *\end{array}$ \\
\hline Pure date juice & 100 & - & - & 0.3 & 0.125 \\
\hline $\begin{array}{l}\text { Date-cinnamon juice } \\
(98.75: 1.25 \%)\end{array}$ & 98.75 & - & 12.5 & 0.3 & 0.125 \\
\hline $\begin{array}{l}\text { Date-cinnamon juice } \\
(97.5: 2.5 \%)\end{array}$ & 97.5 & - & 25 & 0.3 & 0.125 \\
\hline $\begin{array}{l}\text { Date-pomegranate juice } \\
(75: 25)\end{array}$ & 75 & 25 & - & 0.3 & 0.125 \\
\hline $\begin{array}{l}\text { Date-pomegranate juice } \\
(50: 50)\end{array}$ & 50 & 50 & - & 0.3 & 0.125 \\
\hline
\end{tabular}

* Citric acid and Guar gum were added by the same ratios for $100 \mathrm{ml}$ of each juice blend. 


\section{Total polyphenols:}

Folin-Ciocalteau method was used to determine total polyphenol content (TPC) by recording the absorbance at $765 \mathrm{~nm}$ (UV-Vis spectrophotometer, Jenway, Staffordshire, UK), (Gao et al., 2000). Total phenol content was expressed as gallic acid equivalents in $\mathrm{mg} / \mathrm{L}$.

\section{Total Flavonoids Content:}

Flavonoids content was measured by the method described by Yoo et al., 2008. Where the absorption at $510 \mathrm{~nm}$, was read. Levels of total flavonoid content $(\mathrm{mg} / \mathrm{L})$ were expressed as quercetin equivalents.

\section{Total Anthocyanins Content:}

Total anthocyanin contents were measured by a spectrophotometric $\mathrm{pH}$ differential protocol reported by Giusti and Wrolstad, 2001. $0.5 \mathrm{~mL}$ of each juice was blended with $3.5 \mathrm{~mL}$ of both of $\mathrm{KCl}$ buffer $(0.025 \mathrm{M}$, $\mathrm{pH} 1)$ and sodium acetate buffer $(0.025 \mathrm{M}, \mathrm{pH} 4.5)$. The absorbance of each mixture was read after $15 \mathrm{~min}$, at 510 and $700 \mathrm{~nm}$. Results are expressed as $\mathrm{mg}$ of cyanidin 3-glucoside equivalents/L.

\section{Determination of total viable count (TVC):}

Total viable count was achieved as described by Frazier (1976), $1 \mathrm{ml}$ of studied juices was added to $9 \mathrm{ml}$ of ringer's solution into a sterile test tube, the sample was blended thoroughly by mixing to prepare 10 serial dilutions. Three sterile petri-dishes were inoculated by each dilution then slight layer of nutrient agar was added. The inoculated petri-dishes were gentle shaken and left to hardens and then incubated for 24 hours on $37^{\circ} \mathrm{C}$. After incubation period the colonies number were recorded and expressed as cfu $/ \mathrm{ml}$. of date juice.

\section{Yeast and mold enumeration:}

Yeast and mold counts were determined using the plate counts technique on potato dextrose agar (PDA) according to procedures by A.P.H.A (1976) and Difco (1984). The plates were kept 3 days at $28^{\circ} \mathrm{C}$.

\section{Sensory evaluation:}

Sensory quality of the new date juices was evaluated by 15 panelists from the staff of Agri-Industrialization Unit, Desert Research Center. Panelists were asked to evaluate appearance, color, taste, odor, viscosity, sweetness, acidity and over all acceptability, using seven points hedonic scale with corresponding descriptive terms ranging from 7 'like extremely' to 1 'dislike extremely'.

\section{Statistical analysis:}

A completely randomized experimental design was selected to define the treatments effect. All determinations were carried out in triplicate and data was reported as mean. Significant differences $(p<0.05)$ were calculated using Duncan multiple rang tests, followed the method reported by Steel and Torrie (1980).

\section{RESULTS AND DISCUSSION}

The Total soluble solids (TSS), reducing sugars and total sugars of the studied date juice blends at zero time and during 3 months of storage at room temperature were determined and the obtained data were presented in Table2.

The tabulated data in Table (2), illustrated that, all studied juice blends recorded an increase in TSS by increasing the storage period, this increase reached the highest value after 3 months of storage at room temperature for each juice separately. This increment could be attributed to the transformation of some insoluble components (such protopectin) into soluble components (such pectin), Thompson and Abboodi (2003).

Also, increasing cinnamon concentration from 1.25 to $2.5 \%$ led to slight insignificant increase in TSS (from 19.2 to $19.4 \%$ ), while the opposite situation was observed by increasing pomegranate concentration from 25 to $50 \%$ which led to insignificant decrease in TSS from 18.9 to $18.6 \%$.

These findings were in accordance with those of Rani et al., 2018, who found that, TSS of Mandarin and Strawberry mixed fruit juice samples increased by increasing storage period till 90 days at room temperature.

Sugars act as natural preservative in some food products. In the same time sugars (which considered the most important fruit component) give some food products their characterized flavor.

Results in Table 2, showed that, the progress of storage period resulted in an increase in reducing sugars for all studied juice mixtures, this increase reached maximum value after 3 months of storage at room temperature for each juice sample separately. The reducing sugars increment could be attributed to transformation of sucrose to glucose and fructose (reducing sugars), as a result of storage period and temperature as well as natural acids. Shakoor et al., 2013

Also, increasing cinnamon and pomegranate ratios led to decrease reducing sugars from 13.5 to $13.2 \%$, and from 12.5 to $12.1 \%$, respectively. 
Table 2. Total soluble solids, reducing sugars and total sugars of date juice blends during three months of storage at room temperature

\begin{tabular}{|c|c|c|c|c|}
\hline \multicolumn{5}{|c|}{ TSS } \\
\hline & Zero time & 30 days & 60 days & 90 days \\
\hline Date juice & $18.3^{\mathrm{cC}}$ & $19.1^{\mathrm{dB}}$ & $19.1^{\mathrm{dB}}$ & $19.5^{\mathrm{cA}}$ \\
\hline Cinnamon $1.25 \%$ & $19.2^{\mathrm{abD}}$ & $19.8^{\mathrm{aC}}$ & $20.1^{\mathrm{bB}}$ & $20.3^{\mathrm{bA}}$ \\
\hline Cinnamon $2.5 \%$ & $19.4^{\mathrm{aD}}$ & $19.6^{\mathrm{bC}}$ & $20.3^{\mathrm{aB}}$ & $20.6^{\mathrm{aA}}$ \\
\hline Pomegranate $25 \%$ & $18.9^{\mathrm{bD}}$ & $19.4^{\mathrm{cC}}$ & $19.8^{\mathrm{cB}}$ & $20.2^{\mathrm{bA}}$ \\
\hline Pomegranate $50 \%$ & $18.6^{\mathrm{bD}}$ & $19.3^{\mathrm{cC}}$ & $19.8^{\mathrm{cB}}$ & $20.3^{\mathrm{bA}}$ \\
\hline \multicolumn{5}{|c|}{ Reducing sugars } \\
\hline Date juice & $12.7^{\mathrm{cB}}$ & $13.0^{\mathrm{bB}}$ & $13.4^{\mathrm{cA}}$ & $13.6^{\mathrm{cA}}$ \\
\hline Cinnamon $1.25 \%$ & $13.5^{\mathrm{aC}}$ & $13.8^{\mathrm{aB}}$ & $14.1^{\mathrm{aA}}$ & $14.3^{\mathrm{aA}}$ \\
\hline Cinnamon $2.5 \%$ & $13.2^{\mathrm{bD}}$ & $13.5^{\mathrm{aC}}$ & $13.8^{\mathrm{bB}}$ & $14.1^{\mathrm{bA}}$ \\
\hline Pomegranate $25 \%$ & $12.5^{\mathrm{cD}}$ & $12.9^{\mathrm{bcC}}$ & $13.2^{\mathrm{cB}}$ & $13.5^{\mathrm{cA}}$ \\
\hline Pomegranate $50 \%$ & $12.1^{\mathrm{dC}}$ & $12.6^{\mathrm{cB}}$ & $12.8^{\mathrm{dB}}$ & $13.2^{\mathrm{dA}}$ \\
\hline \multicolumn{5}{|c|}{ Total sugars } \\
\hline Date juice & $15.5^{\mathrm{bD}}$ & $15.9^{\mathrm{cC}}$ & $16.1^{\mathrm{cB}}$ & $16.4^{\mathrm{bA}}$ \\
\hline Cinnamon $1.25 \%$ & $16.1^{\mathrm{aD}}$ & $16.5^{\mathrm{aC}}$ & $16.8^{\mathrm{aB}}$ & $17.0^{\mathrm{aA}}$ \\
\hline Cinnamon $2.5 \%$ & $15.9^{\mathrm{aD}}$ & $16.2^{\mathrm{bC}}$ & $16.6^{\mathrm{bB}}$ & $17.0^{\mathrm{aA}}$ \\
\hline Pomegranate $25 \%$ & $15.6^{\mathrm{bD}}$ & $15.8^{\mathrm{cC}}$ & $16.2^{\mathrm{cB}}$ & $16.5^{\mathrm{bA}}$ \\
\hline Pomegranate $50 \%$ & $15.2^{\mathrm{cD}}$ & $15.3^{\mathrm{dC}}$ & $15.7^{\mathrm{dB}}$ & $16.2^{\mathrm{cA}}$ \\
\hline
\end{tabular}

Values bearing the same superscript (capital letters) within the same row are not significantly different $(\mathrm{P} \leq 0.05)$

Values bearing the same superscript (small letters) within the same column are not significantly different $(\mathrm{P} \leq 0.05)$

Also, increasing cinnamon and pomegranate ratios led to insignificant reduction in total sugars for cinnamon blends, whereas significant reduction was recorded for pomegranate blends at zero time (from 15.6 to $15.2 \%$ ).

The previous results were in accordance with those obtained by Sunil et al., (2011), who found that both reducing and total sugar contents increased during refrigerated storage of Nagpur mandarin for six months. They mentioned that, the total sugars increment could be attributed to the degradation of polysaccharides such starch, cellulose and pectin and their transformation into simple sugars.

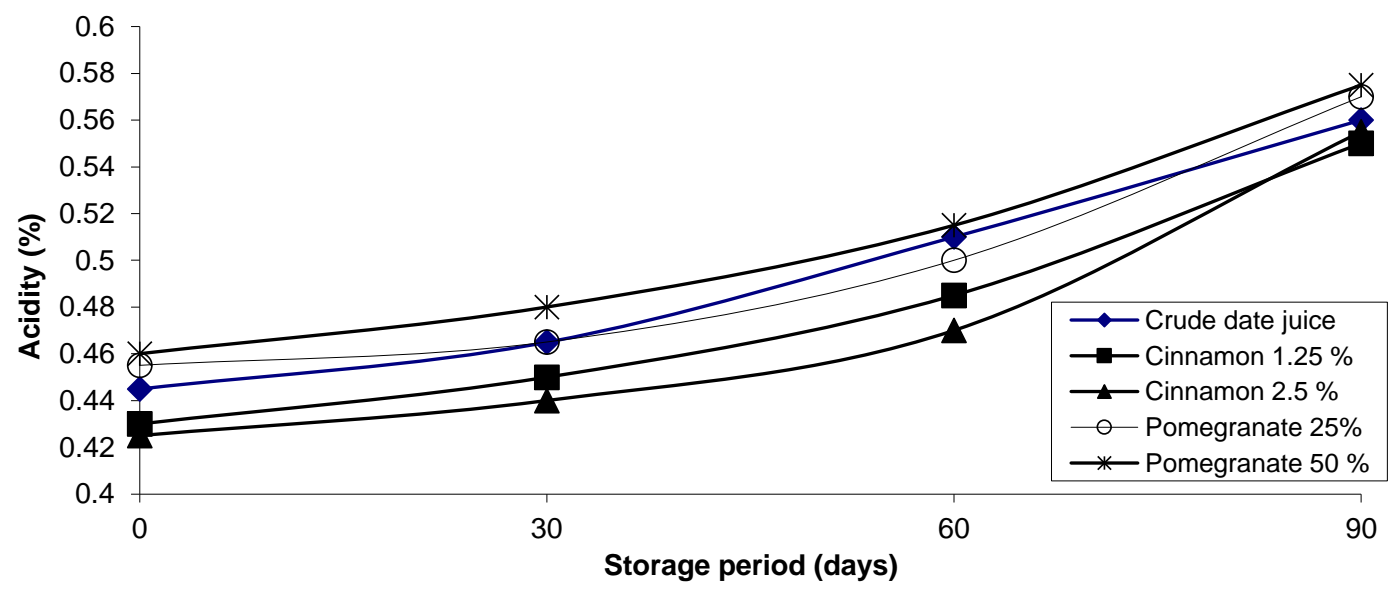

Fig.1. Acidity (\%) of Date juice blends during three months of storage at room temperature 


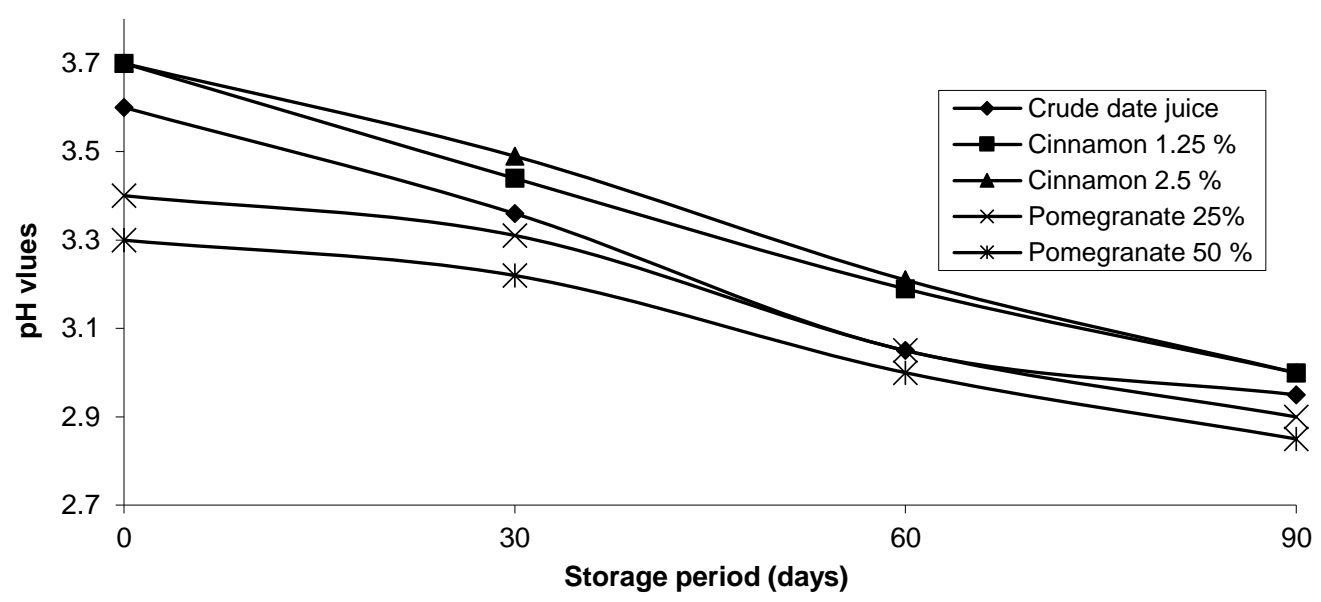

Fig.2. pH values of Date juice blends during three months of storage at room temperature

Results of Acidity (\%) and $\mathrm{pH}$ that presented in fig. (1) and fig. (2), showed that, the highest acidity and the lowest $\mathrm{pH}$ value at zero time were recorded for the juice blend consisted of 50\%: $50 \%$ (pomegranate juice and date juice) followed by the juice blend consisted of $25 \%$ pomegranate juice and $75 \%$ date juice. This may be due to the organic acids that naturally present in pomegranate juice.

From the previous data, it could be noticed that, the progress of storage period the higher of acidity and the lower of $\mathrm{pH}$ value for all studied date juices. These findings are in complete agreement with Saeed et al., (2010), who found that, there was an increase in acidity and decrease in $\mathrm{pH}$ during storage of mango pulp at room temperature for three months. This may be due to acids formation as a result of polysaccharides breakdown and reducing sugars oxidation or by degradation of pectic substances and uronic acid (Hussain et al., 2008).

The presented data in table (3), demonstrated obviously that, blending date juice with cinnamon or pomegranate led to improve its contents of polyphenols, flavonoids and anthocyanins. This improvement increased by increasing the level of cinnamon or pomegranate, but the highest effect was recorded for $50 \%$ pomegranate juice $(630,155$ and $85 \mathrm{mg} / 100 \mathrm{ml}$ juice, respectively)

From the same table, it could be noticed that, extending the storage period till three months resulted in degradation of flavonoids and anthocyanins for all studied date juice blends, while polyphenols recorded fluctuation trend, this might be due to the formation of some compounds during storage that were able to react with the Folin-Ciocalteu and then enhance the amount of this antioxidant.The common method for assessment of total polyphenol content is Folin-Ciocalteu's method; although, Folin-Ciocalteu's reagent is nonspecific, where the presence of ascorbic acid, organic acids, aromatic amines, Sulphur dioxide, reducing sugars and other components that found naturally in fruit juices, obtained unstable results Castro-López et al., (2016).

These findings were in accordance with those of Urszula et al., (2017), who found that, flavonoids, underwent significant breakdown during storage of the raspberry juices and syrups. They also illustrated that. anthocyanins significantly decreased in all studied samples during five-months of storage.

Concerning the microbiological quality of the studied date juice blends, total bacterial count and mold and yeast counts were evaluated and the obtained results were presented in fig (3) and fig (4).

From the presented data, it could be observed that, either pomegranate or cinnamon treatments led to improve the microbial quality of the produced juice blends (during storage period) by reducing both of total bacterial count and mold and yeast count comparing to pure date juice. But the highest positive effect was recorded for date pomegranate juice blend (50\%: 50\%). These could be due to the higher content of total polyphenols and flavonoids. 
Table 3. Polyphenols, Flavonoids and Anthocyanins contents $(\mathrm{mg} / 100 \mathrm{ml})$ of date fruit juices during three months of storage at room temperature

\begin{tabular}{|c|c|c|c|c|}
\hline \multicolumn{5}{|c|}{ Polyphenols (mg/100ml) } \\
\hline & Zero time & 30 days & 60 days & 90 days \\
\hline Date juice & $380^{\mathrm{dA}}$ & $365^{\mathrm{dB}}$ & $375^{\mathrm{dA}}$ & $360^{\mathrm{dB}}$ \\
\hline Cinnamon $1.25 \%$ & $480^{\mathrm{cA}}$ & $470^{\mathrm{cBC}}$ & $475^{\mathrm{cAB}}$ & $465^{\mathrm{cC}}$ \\
\hline Cinnamon $2.5 \%$ & $530^{\mathrm{bB}}$ & $535^{\mathrm{bA}}$ & $515^{\mathrm{bcD}}$ & $525^{\mathrm{bC}}$ \\
\hline Pomegranate $25 \%$ & $540^{\mathrm{bB}}$ & $530^{\mathrm{bC}}$ & $550^{\mathrm{bA}}$ & $525^{\mathrm{dB}}$ \\
\hline Pomegranate $50 \%$ & $630^{\mathrm{aA}}$ & $625^{\mathrm{aA}}$ & $640^{\mathrm{aA}}$ & $620^{\mathrm{aA}}$ \\
\hline \multicolumn{5}{|c|}{ Flavonoids (mg/100ml) } \\
\hline Date juice & $95^{\mathrm{dA}}$ & $85^{\mathrm{dB}}$ & $80^{\mathrm{eB}}$ & $60^{\mathrm{eC}}$ \\
\hline Cinnamon $1.25 \%$ & $115^{\mathrm{cA}}$ & $110^{\mathrm{cA}}$ & $95^{\mathrm{dB}}$ & $80^{\mathrm{dC}}$ \\
\hline Cinnamon $2.5 \%$ & $130^{\mathrm{bA}}$ & $120^{\mathrm{bB}}$ & $110^{\mathrm{bC}}$ & $95^{\mathrm{bD}}$ \\
\hline Pomegranate $25 \%$ & $135^{\mathrm{bA}}$ & $120^{\mathrm{bB}}$ & $105^{\mathrm{cC}}$ & $85^{\mathrm{cD}}$ \\
\hline Pomegranate $50 \%$ & $155^{\mathrm{aA}}$ & $150^{\mathrm{aB}}$ & $135^{\mathrm{aC}}$ & $125^{\mathrm{aD}}$ \\
\hline \multicolumn{5}{|c|}{ Anthocyanins (mg/100ml) } \\
\hline Date juice & $25^{\mathrm{eA}}$ & $20^{\mathrm{eB}}$ & $12^{\mathrm{eC}}$ & $8^{\mathrm{dD}}$ \\
\hline Cinnamon $1.25 \%$ & $50^{\mathrm{dA}}$ & $40^{\mathrm{dB}}$ & $35^{\mathrm{dC}}$ & $25^{\mathrm{cD}}$ \\
\hline Cinnamon $2.5 \%$ & $60^{\mathrm{cA}}$ & $55^{\mathrm{cB}}$ & $45^{\mathrm{cC}}$ & $40^{\mathrm{bD}}$ \\
\hline Pomegranate $25 \%$ & $75^{\mathrm{bA}}$ & $60^{\mathrm{bB}}$ & $55^{\mathrm{bC}}$ & $42^{\mathrm{bD}}$ \\
\hline Pomegranate $50 \%$ & $85^{\mathrm{aA}}$ & $75^{\mathrm{aB}}$ & $60^{\mathrm{aC}}$ & $47^{\mathrm{aD}}$ \\
\hline
\end{tabular}

Values bearing the same superscript (capital letters) within the same row are not significantly different $(\mathrm{P} \leq 0.05)$

Values bearing the same superscript (small letters) within the same column are not significantly different $(\mathrm{P} \leq 0.05$

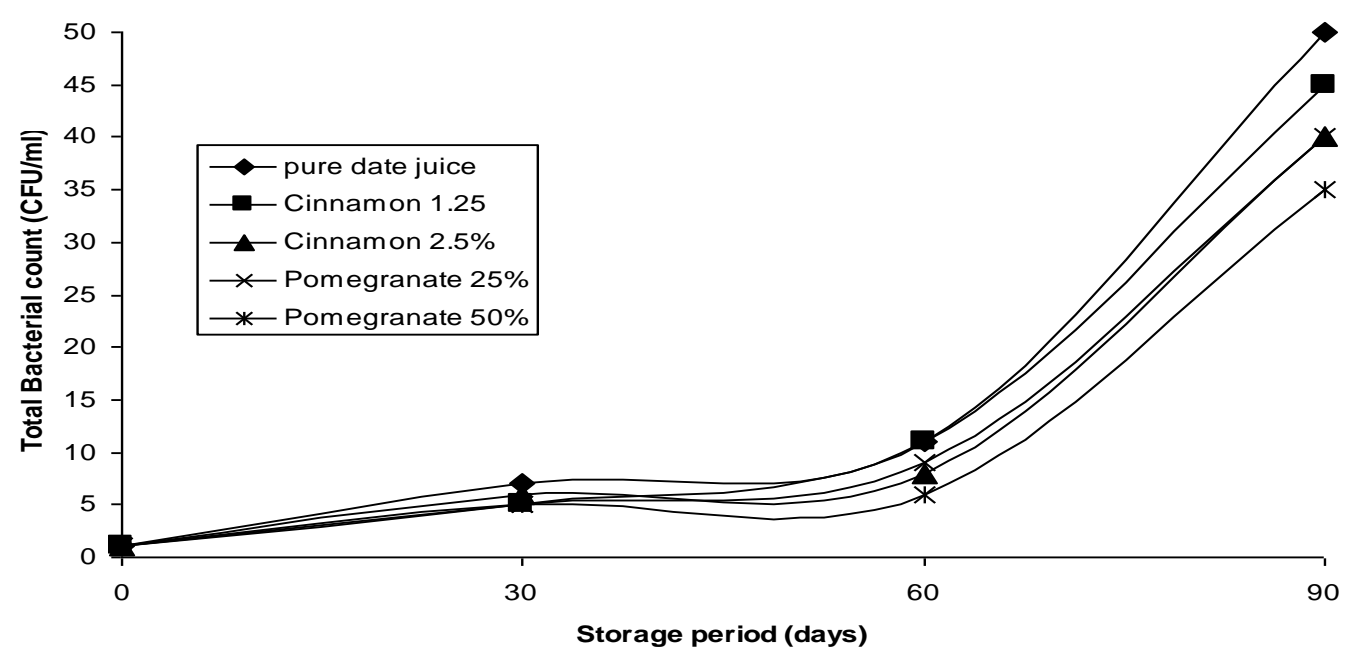

Fig.3. Total Bacterial count $(\mathrm{cfu} / \mathrm{ml})^{*} 10^{2}$ of Date juice blends during three months of storage at room temperature 


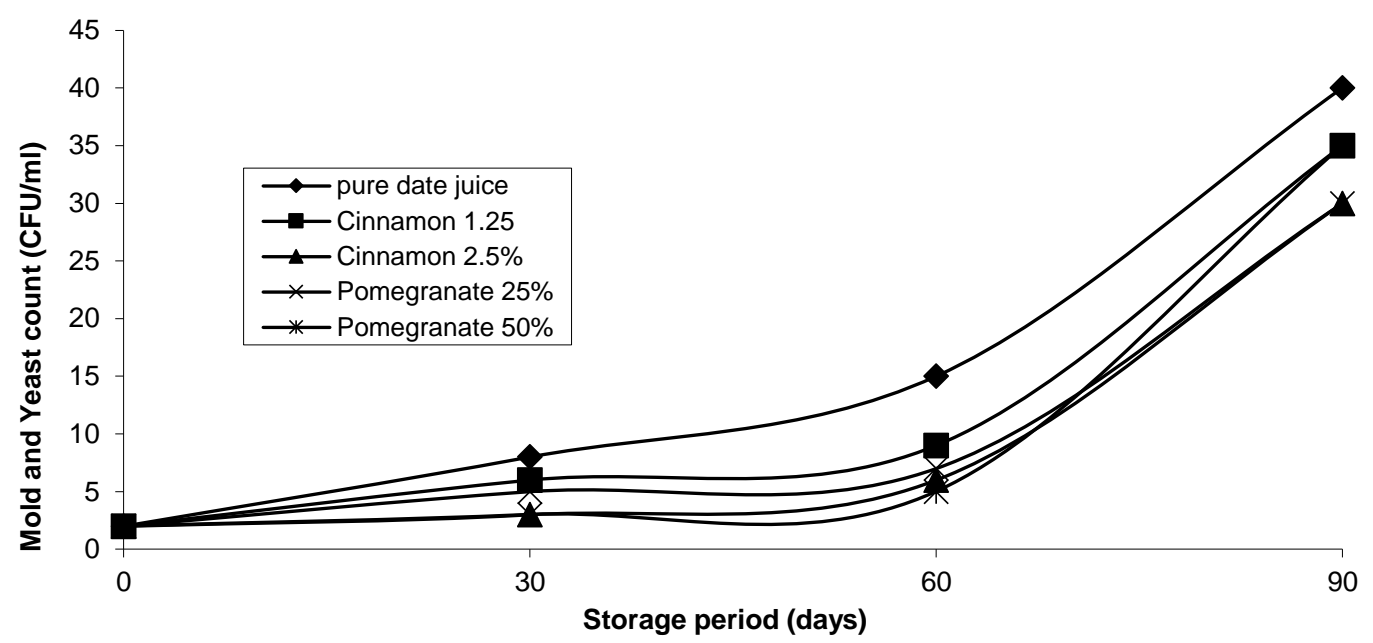

Fig. 4. Mold and Yeast count $(\mathrm{cfu} / \mathrm{ml}) * 102$ of date juice blends during three months of storage at room temperature

Also, the mentioned data, indicated that, all studied date juice blends had acceptable microbial quality where, total aerobic bacterial counts were used as indicators of quality and counts $>10^{4} \mathrm{cfu} / \mathrm{ml}$ can provide useful information about the general quality and remaining shelf life of the cooked food in question. Where the upper acceptable limit of total aerobic counts is $10^{4} \mathrm{cfu} / \mathrm{ml}$ (Center for Food Safety, 2014).

Sensory evaluation of date juice blends was carried out and the results were tabulated in table (4). The mentioned data in table (4), illustrated that, all studied samples were sensorial accepted (there was no value below 4). The previous data showed obviously that, all studied blends led to improve the appearance, color, sweetness and acidity comparing with pure date juice sample which recorded the lowest values $(5.28,5.13$, 5.07 and 4.68 , respectively). While the lowest values of taste, odor, viscosity and over all acceptability were recorded for date pomegranate blend (50\%:50\%). On the other hand, the highest scores of appearances, color, taste, viscosity and over all acceptability $(6.02,5.88$, $5.63,5.39$ and 5.84 , respectively) were recorded for date cinnamon blend (98.75:1.25\%), while the highest scores of odor and sweetness (5.73 and 5,57, respectively) were recorded for date cinnamon blend (97.5:2.5\%).

Table 4. Sensory Evaluation of fresh date fruit juices

\begin{tabular}{lcccccccc}
\hline & Appearance & Color & Taste & Odor & Viscosity & Sweetness & Acidity & $\begin{array}{c}\text { Over all } \\
\text { acceptability }\end{array}$ \\
\hline $\begin{array}{l}\text { Pure Date } \\
\text { juice }\end{array}$ & $5.28^{\mathrm{d}}$ & $5.13^{\mathrm{e}}$ & $5.18^{\mathrm{c}}$ & $5.24^{\mathrm{c}}$ & $5.18^{\mathrm{ab}}$ & $5.07^{\mathrm{c}}$ & $4.68^{\mathrm{c}}$ & $5.44^{\mathrm{b}}$ \\
\hline $\begin{array}{l}\text { Cinnamon } \\
1.25 \%\end{array}$ & $6,02^{\mathrm{a}}$ & $5.88^{\mathrm{a}}$ & $5.63^{\mathrm{a}}$ & $5.68^{\mathrm{a}}$ & $5.39^{\mathrm{a}}$ & $5.47^{\mathrm{ab}}$ & $4.75^{\mathrm{c}}$ & $5.84^{\mathrm{a}}$ \\
\hline $\begin{array}{l}\text { Cinnamon } \\
2.5 \%\end{array}$ & $5.39^{\mathrm{cd}}$ & $5.44^{\mathrm{c}}$ & $5.57^{\mathrm{a}}$ & $5.73^{\mathrm{a}}$ & $5.15^{\mathrm{ab}}$ & $5.57^{\mathrm{a}}$ & $4.89^{\mathrm{b}}$ & $5.78^{\mathrm{a}}$ \\
\hline $\begin{array}{l}\text { Pomegranate } \\
25 \%\end{array}$ & $5.71^{\mathrm{b}}$ & $5.57^{\mathrm{b}}$ & $5.34^{\mathrm{b}}$ & $5.50^{\mathrm{b}}$ & $5.05^{\mathrm{b}}$ & $5.18^{\mathrm{c}}$ & $5.28^{\mathrm{a}}$ & $5.50^{\mathrm{b}}$ \\
\hline $\begin{array}{l}\text { Pomegranate } \\
50 \%\end{array}$ & $5.52^{\mathrm{c}}$ & $5.33^{\mathrm{d}}$ & $4.86^{\mathrm{d}}$ & $5.13^{\mathrm{c}}$ & $4.94^{\mathrm{b}}$ & $5.38^{\mathrm{b}}$ & $5.31^{\mathrm{a}}$ & $5.36^{\mathrm{b}}$ \\
\hline
\end{tabular}

Values bearing the same superscript within the same column are not significantly different $(\mathrm{P} \leq 0.05)$ 


\section{CONCLUSION}

Using Siwi fruits at khalal stage in production of new juices (mixed with pomegranate or cinnamon), led to produce date juice blends with higher content of polyphenols, flavonoids, anthocyanins in comparison with pure date juice, whereas pomegranate led to decrease TSS, Reducing and total sugars in opposite situation with cinnamon. Also, adding pomegranate or cinnamon resulted in improving the microbial quality of the produced juices comparing to pure date juice. Sensory evaluation demonstrated that all studied date juices were accepted organoleptically. From the mentioned results it could be concluded that, Siwi date fruits at khalal stage (separately or combined with pomegranate or cinnamon) could be used in production of new, delicious and nutritional juices.

\section{REFERENCES}

Abdel Baki, A.A. 1983. Hydrological and Hydrogeochemical Studies on the Area West of Rosetta Branch and South of El-Nasr Canal: Ph.D. Thesis, Fac. Sci., Ain Shams Univ., Cairo, Egypt, 122p.

AbdEl-Hady, A.M and E.F. Abdelaty. 2019. GIS Comprehensive Analytical Approach for Soil Use by Linking Crop Soil Suitability to Soil Management and Reclamation. Alex. Sci. Exch. J. 40: 60-82.

Abdel-Kader, M.M., B.R. Ismail, M.M. Diab and E.A. Hassan. 1998. Preliminary evaluation of some soilborne fungi parasitiz-ing Orobanche crenata in greenhouse. In "6th Mediteranean symposium. EWRS", pp. 127-132, Montpellier, France.

Abdrabbo, M.A.A., A.A. Khalil, M.K.K. Hassanien and A.F. Abou-Hadid. 2010. Sensitivity of Potato Yield to Climate Change. Journal of Applied Sciences Research .6:751-755.

Alam, H., J.Z. Khattak, S.B. Ppoyil, S.S. Kurup and T. Ksiksi. 2017. Landscaping with native plants in the UAE: A review. Emirates Journal of Food and Agriculture .29:729741.

Ali, H.G., D.M. Yacout, S.F. Shaheen and A.H. Rabia. 2018. Assessment of Climate Change Impacts on Barley Production in Rain-Fed Areas in Northern Egypt. In "2nd International Conference of Biotechnology and Environment (ICBE) ".

Attia, S.H. 1975. Pedology and Soil Genesis of the Quaternary Deposits in the Region West of the Nile Delta, North and East of Wadi El-Natrun: Ph.D. Thesis, Fac. Sci., Ain Shams Univ., Cairo, Egypt, 258p.

Center of Agriculture Research. 2003. Ministry of agriculture and land reclamation economic affairs sector.

Daccache, A., E.K. Weatherhead, M.A. Stalham and J.W. Knox. 2011. Impacts of climate change on irrigated potato production in a humid climate. Agr. Forest Meteorol. $151: 1641-1653$
Egypt National Report .2018. Addis Ababa Declaration on Population and Development in Africa beyond 2014 $(\mathrm{AADPD}+5)$.

EI-Fayumy, I.F. 1964. Geology of Groundwater Supplies in Wadi El-Natrun Area: M.Sc. Thesis, Fac. Sci., Cairo Univ., Egypt, 109p.

FAO .2006. Food and Agriculture Organization of the United Nations, Rome. .

FAO. 1997. "Plant nematode problems and their control in the Near East region: proceedings of the Expert Consultation on Plant Nematode Problems and their Control in the Near East Region." Food and Agriculture Organization of the United Nations, Rome, Karachi, Pakistan.

FAO. 2015. "Food and Agriculture Organization of the United Nations, Rome, 2015. FAO Statistical Pocketbook (http://www.fao.org/3/a-i4691e.pdf). "

FAOSTAT .2018. The database of the United Nations Food and Agriculture Organization statistical database. Retrieved from http://www.fapstat.org

Haverkort, A.J., A.C. Franke, F.A. Engelbrecht and J.M. Steyn .2013. Climate Change and Potato Production in Contrasting South African Agro-ecosystems: Effects on Land and Water Use Efficiencies. Potato Research. 56:3150 .

Hijmans, R.J. 2003. The Effect of Climate Change on Global Potato Production. . Amer J of Potato Res. 80:271-280.

IPCC .2018. "Global Warming of $1.5^{\circ} \mathrm{C}$. An IPCC Special Report on the impacts of global warming of $1.5^{\circ} \mathrm{C}$ above pre-industrial levels and related global greenhouse gas emission pathways, in the context of strengthening the global response to the threat of climate change, sustainable development, and efforts to eradicate poverty [V. MassonDelmotte, P. Zhai, H. O. Pörtner, D. Roberts, J. Skea, P.R. Shukla, A. Pirani, W. Moufouma-Okia, C. Péan, R. Pidcock, S. Connors, J. B. R. Matthews, Y. Chen, X. Zhou, M. I. Gomis, E. Lonnoy, T. Maycock, M. Tignor, T. Waterfield (eds.)].".

Knox, J.W and S. Wade. 2012. Assessing climate risks to UK agriculture. Nature Climate Change. 2-378.

Omara, S.M and S. Sanad. 1975. Rock Stratigraphy and Structural Features of the Area Between Wadi El-Natrun and Moghra Depression, Western Desert Egypt: Geol. J., BL.6, Hanover, pp.45-73.

Rabia, A.H., D.M. Yacout and S.F. Shaheen. 2016. Towards Sustainable Potato Production under Climate Change Conditions: a community-based adaptation approach. In " The 43rd, Annual Conference of the Association of Egyptian-American Scholars (AEAS), Zewail City of Science and Technology (ZC), " Giza, Egypt.

Rabia, A.H., D.M.M. Yacout, S.F. Shahin, A.A.A. Mohamed and E.F. Abdelaty. 2018. Towards Sustainable Production of Potato under Climate Change Conditions. Current Applied Science and Technology .18:200-207.

Raymundo, R., S. Asseng, D. Cammarano and R. Quiroz 2014. Potato, sweet potato, and yam models for climate change: A review. Field Crops Research.166:173-185. 
Shaheen, S.F., D.M. Yacout and A.H. Rabia. 2016. Comparison between Potato (Solanum tuberosum L.) Cultivars and Abiotic stress genes. In "The international conference "EnviroInfo 2016 - Environmental Informatics - Stability, Continuity, Innovation: Current trends and future perspectives based on 30 years of history", HTW University, Berlin, Germany.

Shata, A.A and I.F. El-Fayoumy. 1969. Remarks on the Hydrogeology of the Nile Delta: Sympos. Hydrology of Delta, UNESCO, Vol.2, pp. 385-396.

Shata, A.A. 1955. An Introductory Note on the Geology of the Northern Portion of the Western Desert of Egypt: Bull. Inst. Desert, Egypt, T.5, No.3, pp. 96-106.

Shata, A.A. 1962. Geology, In Preliminary Reports on Geology, Hydrology and Groundwater Hydrogeology of Wadi El-Natrun and Adjacent Areas. Part 1; Cairo, U.A.R., Desert Institute, the General Desert Development Organization, 39p.
Shata, A.A., E.-F.I. F and M. Tamer. 1970. Geomorphology, Geology, Hydrogeology and Soil of Wadi El-NatrunMaryut Agriculture Project: Int. Rep., Desert instit., 19p.

Shieded, A.G. 1989. Geological and Hydrogeological Studies of El-Sadat and its Vicinities: M.Sc. Thesis, Fac. Sci, ElMenoufia Univ., Shibin El-Kom, Egypt, 157p.

SIS .2016. State Information System www.sis.gov.eg

Supit, I., C. Van Diepen, A. De Wit, J. Wolf, P. Kabat, B. Baruth and F. Ludwig. 2012. Assessing climate change effects on European crop yields using the Crop Growth Monitoring System and a weather generator. Agricultural and Forest Meteorology .164:96-111.

Tubiello, F., C. Rosenzweig, R. Goldberg, S. Jagtap and J. Jones. 2002. Effects of climate change on US crop production: simulation results using two different GCM scenarios. Part I: wheat, potato, maize, and citrus. Climate research. 20:259-270.

\section{الملخص العريي \\ استخدام التمر السيوى فى انتاج بعض العصائر الجديدة \\ فؤاد عمر فؤاد أبوزبد}

المواد الصلبة الذائبة الكلية والسكريات المختزلة والكلية وذلك على عكس القرفة ـ كذلك فإن إضافة الرمان أو القرفة أدى إلى تحسين الجودة الميكروبية للعصائر الناتجة مقارنة بعصير البلح الخالص. ولقد أوضحت نتائج التقييم الحسى أن كل العصائر تحت الدراسة كانت مقبولة حسيا. ولقد أظهرت النتائج المشار إليها أن ثمار التمر السيوى فى مرحلة الخلال (سواء منفردة أومخلوطة مع الرمان أوالقرفة) يمكن أسنخدامها فى إنتاج عصائر جديدة ولذيذة ومغذية.

الكلمات المفتاحية: ثمار التمر السيوى، مرحلة الخلا،

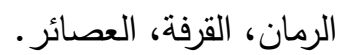

يعتبر صنف التمر السيوى أهم صنف فى التمور النصف جافة فى مصر، وفى مرحلة الخلال تكون ثماره منخفضة السعر والقيمة التسويقية كنتيجة لقصر عمرها ـ لذلك فإن هذا العمل يهدف إلى الإستفادة من ثمار السيوى فى مرحلة الخلال فى إنتاج عصائر جديدة (منفردة أومخلوطة مع الرمان أوالقرفة) إلى جانب تقييم هذه العصائر الجديدة كيميائيا وحسيا وميكروبيولوجيا خلال ثنلاث شهور من التخزين على إهى درجة حرارة الغرفة. ولقد أظهرت النتائج أن مخاليط عصير منرولير البلح مع الرمان أوالقرفة كانت أعلى فى محتواها من البولى فينولات والفلافونيدات والأنثوسيانين مقارنة مع عصير البلح الخالص، بينما أدت إضافة الرمان إلى انخفاض كلا من 